\title{
Tsafon
}

Revue d'études juives du Nord

$72 \mid 2016$

Juifs, Israéliens, dans la littérature française et israélienne

\section{Amnon Cohen, Juifs et musulmans en Palestine et en Israël, des origines à nos jours}

\section{Danielle Delmaire}

\section{OpenEdition}

\section{Journals}

Édition électronique

URL : https://journals.openedition.org/tsafon/485

DOI : $10.4000 /$ tsafon.485

ISSN : 2609-6420

Éditeur

Association Jean-Marie Delmaire

Édition imprimée

Date de publication : 1 décembre 2016

Pagination : 176-178

ISSN : $1149-6630$

Référence électronique

Danielle Delmaire, «Amnon Cohen, Juifs et musulmans en Palestine et en Isrä̈l, des origines à nos jours », Tsafon [En ligne], 72 | 2016, mis en ligne le 31 mai 2018, consulté le 24 juin 2021. URL : http:// journals.openedition.org/tsafon/485; DOI : https://doi.org/10.4000/tsafon.485

Ce document a été généré automatiquement le 24 juin 2021.

Tsafon. Revues d'études juives du Nord 


\title{
Amnon Cohen, Juifs et musulmans en Palestine et en Israël, des origines à nos jours
}

\author{
Danielle Delmaire
}

\section{RÉFÉRENCE}

Amnon Cohen, Juifs et musulmans en Palestine et en Israël, des origines à nos jours, Paris, éd. Tallandier/Projet Aladin, coll. « Histoire partagée », 2016, 251 p., $15 €$.

1 Les éditions Tallandier, dans leur Projet Aladin qui œuvre à un rapprochement entre Juifs et Arabes, ont entrepris d'éditer diverses études sur l'histoire des relations entre juifs et musulmans en terre d'islam, comme le Maroc, la Tunisie, l'Algérie, l'Espagne, l'Égypte etc. La direction en a été confiée à Michel Abitbol, spécialiste israélien de l'histoire des juifs au Maghreb, secondé par un comité scientifique présidé par Abdou Filali-Ansary. Ces deux professeurs ont préfacé l'ouvrage d'Amnon Cohen qui appartient à cette collection.

2 L'auteur, professeur à l'université hébraïque de Jérusalem, a publié, depuis une quarantaine d'années, de nombreuses études sur l'histoire des juifs dans l'Empire ottoman et la vie juive en terre d'islam. Ici, il a puisé ses informations dans les abondantes archives du tribunal islamique de la Jérusalem ottomane ainsi que dans The Encyclopaedia of Islam, et dans une importante bibliographie provenant tant d'auteurs juifs que d'auteurs arabes et musulmans.

3 Amnon Cohen présente une histoire complète depuis le $\mathrm{VII}^{\mathrm{e}}$ siècle jusqu'à l'aube du XXI ${ }^{\mathrm{e}}$, comme le précise le titre : " des origines à nos jours », mais il faut reconnaître que c'est surtout le dernier siècle qui a retenu son attention puisqu'il lui consacre $136 \mathrm{p}$. sur les 225 p. de son étude, tandis qu'il réserve une douzaine de p. aux " premières années » c'est-à-dire celles qui précèdent l'avènement de l'Empire ottoman et qui s'étalent sur près d'un millénaire. 
Pour les «premières années » et la période ottomane, A. Cohen rappelle l'ambiguïté de la dhimmitude qui assure à la fois protection et soumission (impôts, insigne jaune etc). Il n'empêche que les juifs parviennent à surmonter les humiliations en se montrant dociles et à vivre de divers métiers que l'auteur détaille avec précision: bijoutiers, bouchers, boulangers, forgerons, commerçants, changeurs et surtout médecins. Mais au fil des siècles, les communautés juives s'appauvrissent et vivent de plus en plus de l'aide de leurs coreligionnaires d'Europe. Elles se rassemblent principalement en quatre villes: Safed, Tibériade, Hébron et surtout Jérusalem où la population juive est majoritaire au XIX ${ }^{e}$ siècle. Mais ce siècle inaugure un processus : l'immigration des juifs d'Europe qui est à l'origine du développement du Nouveau Yishouv tandis que l'autorité ottomane faiblit face aux prétentions des puissances européennes qui veillent sur «l'homme malade».

5 C'est sous le Mandat britannique, conséquence de la défaite turque lors de la Première Guerre mondiale, que l'antagonisme arabo-juif s'exacerbe. Il est d'abord politique et devient religieux, peu à peu à la veille de la Seconde Guerre mondiale. Les deux décennies du Mandat sont marquées par la radicalisation des Arabes et de leur révolte auxquelles répond une radicalisation de certains mouvements juifs comme l'Irgoun. La Grande Bretagne commence à envisager un partage de la Palestine avec la commission Peel (1937). Partage repensé par l'ONU, cette fois, en 1947.

6 En fait, la création d'un nouvel État, juif, n'apporte pas la paix. Le conflit devient israélo-arabe: les armées des États arabes voisins d'Israël fondent sur lui dans l'intention de le faire disparaître alors qu'une part de ses habitants vient d'échapper à la destruction des nazis. La responsabilité de notables arabes comme les familles Husseini et Nashashibi est mise en cause dans la dégradation de la situation. Face aux 800000 réfugiés arabes, l'auteur aligne plus de 600000 juifs expulsés des États arabes du fait du conflit israélo-arabe des années 1950, une population ruinée et complètement démunie qui se réfugie en grande partie en Israël.

7 La fulgurante victoire des Israéliens lors de la guerre des Six Jours n'apporte toujours pas de solution pacifique. Le conflit se concentre sur l'antagonisme non plus juif/arabe mais israélien/palestinien et il ronge l'État d'Israël à l'intérieur : la population araboisraélienne s'insurge tandis que l'armée israélienne doit faire face aux attaques de Palestiniens à partir des territoires qu'elle peine à maîtriser.

Pour les Palestiniens d'Israël surgit un paradoxe : s'intégrer avantageusement dans la société israélienne mais au prix du refoulement de sentiments nationaux voire nationalistes.

9 L'ouvrage n'apporte pas vraiment de nouvelles connaissances sur cette histoire des relations entre juifs et musulmans en Palestine mais il présente une grande fresque rétrospective très utile pour une bonne information sur ces relations trop souvent galvaudées par méconnaissance du grand public. Et c'est là le grand mérite de l'ouvrage.

10 Toutefois, on peut regretter que l'étude se limite aux problèmes politiques pour le $\mathrm{xx}^{\mathrm{e}}$ siècle alors que pour la période des "premières années » et de l'Empire ottoman, l'auteur accorde une grande place à la vie économique et sociale. Finalement, l'auteur démonte deux mythes : celui de l'âge d'or d'une entente entre juifs et musulmans avant la colonisation et celui d'une « suite ininterrompue de sévices » subis par les juifs (p. 7). Et il souligne l'importance de trois faits marquants pour la Palestine : l'instauration de 
l'Empire ottoman dont elle a dépendu pendant plus de cinq siècles, la présence européenne par la colonisation au $\mathrm{xx}^{\mathrm{e}}$ siècle, l'implantation d'un nouvel État juif depuis 70 ans maintenant. Enfin trois cartes essentielles illustrent son propos : la Palestine en 1914, le partage prévu par la commission Peel en 1937 et le partage voté par l'ONU en 1947. 